\title{
Employee Turnover: Causes, Importance and Retention Strategies
}

\author{
Walid Abdullah Al-Suraihi, Siti Aida Samikon, Al-Hussain Abdullah Al-Suraihi, and Ishaq Ibrahim
}

\section{ABSTRACT}

This research aims to understand the causes of employee turnover and retention strategies in an organization. Key research findings indicate that employees have several reasons to leave their workplaces, such as job stress, job satisfaction, job security, work environment, motivation, wages, and rewards. Furthermore, employee turnover has a huge impact on an organization due to the costs associated with employee turnover and can negatively impact the productivity, sustainability, competitiveness, and profitability of an organization. However, the organization must understand the needs of its employees, which will help organizations, adopt certain strategies to improve employee performance and reduce turnover. Thus, implementing strategies will increase job satisfaction, motivation and the productivity of individuals and organizations, which can reduce employment problems, absenteeism, and employee turnover.

Keywords: Turnover Intention, Job Stress, Job Satisfaction, Work Environment, Retention Strategies.

\section{INTRODUCTION}

Employee turnover is a serious problem for many organizations around the world. Indeed, the study of employee turnover intentions has long been a major concern in an organization's management [1]. Turnover is a huge problem for organizations in today's intense global competition [2]. Recently, found that the phenomenon of turnover is a permanent problem for organizations [3]. That would negatively affect the performance and profitability of the organization. On the other hand, employee turnover increases the chances of losing good employees [4]. Therefore, retaining valuable skilled employees is very important to employers, as they are considered essential to the performance and success of an organization [5]. Besides, employee turnover has always been an important issue for managing an organization.

There are consequence costs associated with a turnover that would direct recruitment costs endured while looking for a replacement, lost labour between the time the individual quits and a replacement, lost productivity while departing employee and reduced productivity of the new hire while learning the job [6]. However, high levels of unemployment make it difficult for people to find suitable work, which reduces productivity and innovation for both the individual and the organization, and this would have a negative impact on the economic development of the country [7]. Thus, employee turnover is a major concern for governments and
Submitted : May 19, 2021

Published : June 09, 2021

ISSN: 2507-1076

DOI: $10.24018 /$ ejbmr.2021.6.3.893

\section{Walid Abdullah Al-Suraihi*}

Post Graduate Centre, Limkokwing University of Creative Technology,

Cyberjaya, Malaysia.

(e-mail: walid.alsuraihi@ ${ }^{@}$ gmail.com)

Siti Aida Samikon

Post Graduate Centre, Limkokwing

University of Creative Technology,

Cyberjaya, Malaysia.

Al-Hussain Abdullah Al-Suraihi

Faculty of Economics and Muamalat, USIM, Malaysia.

Ishaq Ibrahim

Faculty of Leadership and Management, USIM, Malaysia.

*Corresponding Author organizations.

Moreover, the turnover rate survey shows that in Malaysia nearly half of $49 \%$ of organizations recorded employee turnover in 2015. The figure below shows the employee turnover rate in Malaysia in 2015. For example, 7\% of organizations have an employee turnover rate of less than $10 \%$, while $11 \%$ of organizations were affected by employee turnover of more than 50\% [8]. Additionally, in Southeast Asia, Malaysia was ranked second highest voluntary turnover rate of $6.0 \%$ and third-highest voluntary turnover rate of $9.5 \%$ [9].

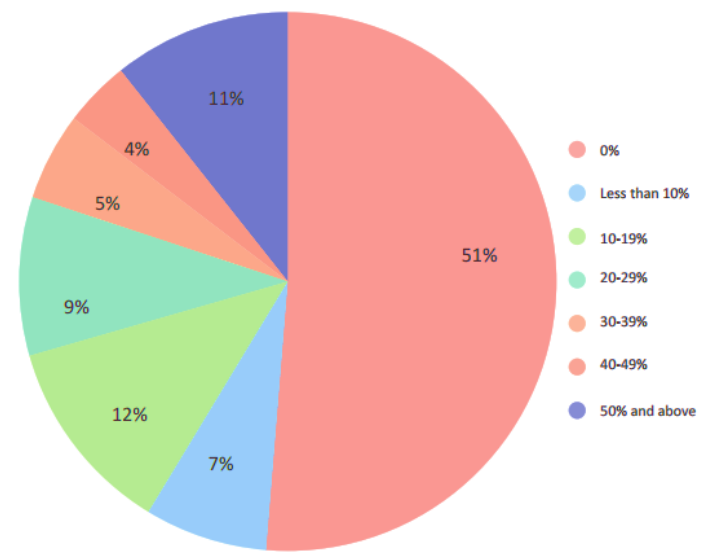

Fig. 1. Malaysian employee turnover rate in 2015.

High turnover rates indicate that worker retention is not a simple task. However, what are the reasons for employee turnover? Is it the fault of a company's management or the 
perspective of the employees?

\section{WhAt MAKES EMPLOYEE TURNOVER?}

Previous researchers focused on what causes the employees to leave an organization and how they left [10], [11]. According to [12] there are several reasons why employees leave work or the organization and these are; employees feel that their work or workplace is not what they expected, also there is a discrepancy between the job and the person. Moreover, there is very little training and feedback, there are very few opportunities for growth and progress. Furthermore, employees feel devalued and unrecognized, employees feel stressed due to overwork and have an imbalance between work and life, and the last reason is a loss of trust in leaders. Moreover, trust is important to the performance and well-being of employees in an organization. Thus, lack of trust is an important reason for employees not to share their knowledge and experience with other members of the organization, which can significantly affect the effectiveness of the organization [13]. Besides, other factors have been identified as career improvement and development, high wage potential, interpersonal conflicts with colleagues, bad human resource policies and personal reasons causing the intention to change [5]. Further, [14] stated that employee turnover is a major concern to companies due to the cost that results from employee turnover and can negatively affect the organization's performance.

Additionally, job-related factors are one of the causes of employee turnover that to some extents are under the direct control of the employer. To illustrate, job-related factors are dissatisfaction with working conditions, supervision disputes, scheduling conflicts or wage inequality, and employers can understand the causes of turnover. The management would be able to identify and solve problems within the organization [10]. Besides, many variables influence the decisions of employees to quit work and can be divided into internal and external variables. Internal variables include issues such as perceived organizational support, pay satisfaction, administrative support, and organizational attractiveness; while external variables include the balance between family work, the labour market and macroeconomic factors [15], [16]. Additionally, satisfaction with the current job, availability of jobs, job switching intention and alignment with their bosses or supervisors are the common reasons for employees to leave an organization [17]. Further, it has been suggested by [18] that a negative evaluation of current employment would lead to dissatisfaction with work, thoughts on resignation, and evaluation of the benefit of job search and the cost of employment.

Moreover, as proposed by [19] based on [20] four factors could be the cause of employee retention or turnover which are, career opportunities available at the organization, mentoring programs for employees, organizational communication policy, and salary and other benefits. Moreover, [21] reported job stress, challenging work and job satisfaction, were affecting employee turnover and absence. Likewise, [22] found that challenging work influences an employee's intention to stay or leave an organization. Further, [23] studied the factors that drive employees to leave work in different sectors. The results suggest that nine factors lead employees to quit or stay in the organization. These include poor working environment, unhelpful colleagues, mismanagement, excessive workload, family pressure, low salary and inappropriate performance appraisal, job security, and rough and tough behaviour of supervisors and bosses.

According to [24] many factors affect employees intention to leave their jobs in palm oil plantations in Malaysia. The results revealed seven factors leading to employee turnover intention, namely salary and well-being, working environment, insecurity, poor organizational support, strict rules and regulations and lack of individual motivation. Moreover, [9] studied the factors that contribute to the turnover of construction industry employees in Malaysia. The work environment, salary, rewards, work and organizational commitment and the leader are important causes for employees leaving their jobs.

Other authors such as [25] specified reasons for employee turnover could be categorised into three groups, first is workrelated factors (e.g., job satisfaction, wage, performance, organizational commitment) second is individual factors (e.g., age, education, gender, tenure) and last is external factors (e.g., unemployment rate, perceptions of employment, presence of trade union). In contrast, there are other causes of employee turnover in non-job-related cases that are usually beyond the control of the employer. These are in the employee's private life that affects their performance at the workplace. Examples of these are relocation and family problems. As stated by [19] the highest number of employees turnover due to job-related reasons is $37.4 \%$ and $29.4 \%$ for non-job-related reasons.

Job satisfaction is an employee's feelings about their job. Job dissatisfaction influences the employees to leave the organization. Further, job dissatisfaction can cause employees to seek other alternatives [26]. If employees are dissatisfied with their job, they may have the intention of leaving the organization, leading them to find employment with other organizations [27]. Furthermore, staff turnover has been studied from different angles. One theory shows that two factors influence a workers decision to resign, the perception of ease of movement, which refers to the assessment of proposed alternatives or opportunities, and the desired to move, which is affected by job satisfaction [28], [29]. Job satisfaction has a negative impact on the turnover intention concerning the nature of the job, supervision and salary [30]. Moreover, job dissatisfaction at the workplace impairs the work capacity of employees, reduces organizational commitment and increases employee intention to leave [31]. Besides, [23] found that job satisfaction has a direct and negative relationship with the employee's intention to leave the job which in turn positively correlates with the actual employee turnover.

Differently, some researchers have found that large groups not only lead to inefficiencies such as loss of motivation, also reduced social interaction and engagement among group members, lower levels of satisfaction and commitment, and lower collective tendency within a workgroup [32]-[35]. Likewise, [36] stated that large groups are unable to cope with the competing pressures of socialization and customer service, which can result in employee turnover among those groups. Furthermore, [27] examined the impact of group cohesiveness on employees' intentions to leave their jobs. 
They found that group cohesion had a negative relationship with employee turnover intention and a positive relationship with job satisfaction. However, [37] investigated the effects of both group cohesion and group size on turnover. Turnover increases in groups with low cohesion .Larger groups had less social interaction and participation among their members, and higher turnover rates.

Work stress is the tension that affects a person's emotions, thoughts, and physical condition [11]. Therefore, employee turnover can be a consequence of burnout due to stresscausing long working hours [38]. Employees who work long hours usually choose to quit their jobs [39]. A study accomplished by [11] revealed that work stress has a positive and significant impact on turnover intention, which could be due to the lack of job satisfaction, including the satisfaction of the salary given by the company. Moreover, [40] indicated that work stress has a significant positive impact on employee turnover intention. Employees who are highly stressed at work are more likely to leave the organization. In this regard, employees who are stressed at work are less satisfied with their jobs and are more likely to consider leaving their jobs [41], [42]. On the other hand, stress is not only a consequence of the workplace but stress can be caused by a work-life imbalance or a conflict between work and family [43], [44]. Work-life balance is a way of reconciling work and private life [44] [45]. Thus, employees can leave the organization because of the extreme stress caused by overworked and the limited personal time they can spend outside work [46]-[48]. Additionally, job burnout is chronic stress to which an employee may be exposed in the workplace. The dimensions of burnout are emotional exhaustion, cynicism, and efficacy among the employees. Burnout is associated with workrelated outcomes such as employee turnover. Thus, burnout predicts the intention of employees to leave their jobs [46], [49]-[51]. Moreover, job burnout has significant consequences for employees, including insomnia, low life satisfaction, and other physical and mental problems [52].

There is some evidence that leaders and managers may affect employee turnover or retention [53], [54]. Furthermore, several factors cause employee turnovers, such as changes in management style, tension with other employees, and distrust [44], [55], [56]. Besides, a lack of leadership management strength leads to employee turnover [57]. The employee decisions to leave influenced by leader behaviours, while inadequate leadership can reduce employee enthusiasm and dissatisfaction [54], [58]. Managers' behaviours and actions, and dissatisfaction could affect intentions to quit and are reciprocated by employee development perceptions [53]. A reason new employees leave the organization is that managers do not allow employees to participate in challenging tasks [59]. Organizational managers positively influence the organizational commitment, work environment, workload were critical to an employee's intent to turnover [60]. In conclusion, the causes of employee turnover are summarized as shown in Table I.
TABLE I: CAUSES OF EMPLOYEE TURNOVER

\begin{tabular}{ccc}
\hline \hline No & Causes & Source \\
\hline 1 & Training and Feedback & {$[12]$} \\
2 & Job-Related Factors & {$[25],[51]$} \\
3 & Trust & {$[55],[56]$} \\
4 & Job Stress & {$[11],[21]$} \\
5 & Challenging Work & {$[22],[59]$} \\
6 & Job Satisfaction & {$[25],[30]$} \\
7 & Working Environment & {$[9],[23]$} \\
8 & Family Pressure & {$[16],[43]$} \\
9 & Salary & {$[5],[24]$} \\
10 & Group Size & {$[32],[37]$} \\
11 & Leaders and Managers & {$[54],[55]$} \\
\hline \hline
\end{tabular}

\section{THE IMPORTANCE OF EMPLOYEE TURNOVER}

Employee behaviour, principles and beliefs affect not only productivity, but also the overall efficiency and effectiveness, and the nature of tasks and collaboration is of paramount importance to employees [61]. Besides, employee turnover has a huge impact on the organization. For example, the organization needs to hire and train new employees, as well as the time the new employee needs to be produced effectively. Besides, employee turnover is expensive from the view of the organization due to the replacement costs for the new employees [62]-[65]. If an employee leaves the company due to a turnover, the assurance of good employee quality is at risk and significant amounts are spent on the selection and training of new employees, which ultimately leads to the loss of the company [66]. Moreover, if employees continue to leave companies, companies should spend time and money hiring and retraining new employees, which negatively affects companies in the long run [67]. High turnover reduces the number of entry-level employees, forcing the use of temporary workers, negatively impacts productivity and competitiveness and hinders skills development [28]. Furthermore, employee turnover can have a negative impact on operating costs and maintain the skills that are necessary to maintain business operations and competitive advantage [63]. Lack of talented and skilled employees can lead to a management problem that affects the productivity, profitability, and quality of products and services. From the workers' point of view, high attrition rates can affect work relationships, morale, and work safety [68].

Organizations have paid much attention to employee turnover because it has huge impacts on organizations [69][73]. Many researchers have found that a high employee turnover rate can negatively impact an organization's profitability if not properly managed [74]-[76]. High employee turnover can have a severe impact on the business, both financially and emotionally [54], [77]. Furthermore, employee turnover is associated with high costs, both on an individual and organizational level. On an individual level, it does not matter whether someone leaves voluntarily for another job or whether he leaves involuntarily and is influenced personally. As for the level of the organisation, the problem arises when employees leave to take their valuable knowledge and experience gained from working with them [78], [79]. Besides, employee turnover is related to the cost in the organization, such as the financial costs associated with employee turnover, recruitment costs and training costs. The cost of replacing an employee, including separation, 
replacement and training costs, is estimated to be between 1.5-2.5 times the employee's annual salary [80]-[82]. Likewise, hiring and training replacement employees can cost companies around $50 \%$ to $60 \%$ of an employee's annual salary, and costs do not stop there [83], [84]. Moreover, high staff turnover will result in financial losses for the organization. Talent replacement can cost up to $25 \%$ of the company's total annual expenses as compensation to the company [85]. Additionally, employee turnover will cost organizations a lot, including money, time, lost productivity, and other resources [49], [75]. Employee turnover has negative consequences in terms of selection and recruitment costs, training and development costs, operational disruption and demoralization of the members in an organization [54], [86], [87]. Every time an employee leaves the company, productivity is reduced due to the learning curve involved in working and understanding the organization, which impacts the organization's profitability [76], [88]. Likewise, the ability of other employees to perform their duties can be affected when an employee leaves an organization [32]. Therefore, the employee turnover caused by miss management would affect the organization negatively in terms of personnel costs and the long run it would affect its liquidity position [89]. However, the turnover intention has a significant effect on organizations through direct costs (replacement, recruitment and selection, temporary staff, management time) and indirect costs (morale, pressure on remaining staff, costs of learning, product/service quality, organizational memory) and last for the loss of social capital [14], [17], [90].

On the other hand, many studies show the impact of employee turnover on customer service and satisfaction [32], [91], [92]. Dealing with customer satisfaction is one of the company's performance measures [93], [94]. Moreover, [95] added that customer satisfaction is become important due to the highly competitive environment in the field of retail, satisfaction is a critical factor in organizations' success, as well as the incentive to purchase or use the service, and is essential to achieve a competitive advantage. Further, [69] found that the employee has a direct impact on the customer, and the relation of employee and customer is an important consideration for a company's success. Many researchers have found that customer satisfaction is related to employee satisfaction, and when employees are satisfied with their job, it leads to better customer service [96], [97]. Besides, another study accomplished by [98] indicated that there is a significant negative relationship between employee and customer satisfaction. As employee turnover increases, customer satisfaction declines. When the employees satisfied would be equal to customers' satisfaction. Likewise, the employees dissatisfied definitely would lead to customers' dissatisfaction. Therefore, Employees are part of the driver behind customer satisfaction. Retail is one of those places where employees interact directly with customers, and which is most important to any business. Employee turnover in an organization can affect customer service due to a negative impact on efficiency, resulting in a loss of human capital and a reduction in the service level of the organization's customers [32], [37]. According to [91] on average employee turnover in a major retail chain is associated with decreased performance, as measured by profit margin and customer service. Additionally, employee turnover can have negative effects on the remaining, as they need to split time between training new employees and performing regular tasks, which in turn leads to decreased efficiency and productivity among the employees in the organization [99], [100]. Hence, while the organization recruit a new employee that has proficiency in their new job, the customer service would suffer as the customers receive service from those new employees who have less experienced and less knowledgeable than former employees, and therefore less aware of the organization's and customers' goals [32].

There is a study done by [101] found that employee turnover negatively affects sales and profits and that this relationship is mediated by specific efficiency as customer waiting time in the fast-food industry etc. The turnover rate also led to increased food waste produced in restaurants. [91] established that the employee turnover has a negative effect on both measures of store performance means the impact of turnover on performance is negative at low-turnover stores for both customer service and profit margin, while these turnover rates included those employees who perform daily operational activities as well as managers and assistant managers. [102] found that turnover rates in the bank sector negatively correlated with customer satisfaction. As stated by [103] retailer customers could be exceeding their expectations when the employees are empowered with knowledge and have access to customers' information. When the employee has great knowledge and training, they will ensure customers stay longer and loyal towards them. Employee and top management support considered as internal factors towards customer satisfaction and retention [94].

Workplace condition is defined as an environment in which employees are prepared to perform their daily work and activities and adapt to the physical and non-physical engagement [104]. The work environment is one of the factors that can influence an employee's decision to stay in a good environment or leave in a bad environment [41]. A high turnover rate could cause low employee morale due to overworked employees who have had increased workloads and responsibilities due to a lack of active or skilled employees; another problem is new employees could suffer from low morale as they struggle to learn new job duties and procedures. Therefore, it becomes difficult for a company to attract and retain world-class talent [105]. The consequences of employee turnover are low morale and decreased motivation that affects the productivity of employees in the organization [106].

Therefore, management should pay special attention to avoid employee turnover which has control, as a strategy to improve employee retention. To reduce employee turnover and retain talent, organizations must focus on adopting different healthy workplace methods; this includes engaging employees in the decision-making process, providing adequate opportunities for growth and development, ensuring a balance between work and personal life, adequate wages, also introducing various health and safety programs as well as other benefits [107]. 


\section{RETENTION STRATEGIES}

The impact of turnover has received considerable attention from senior management, human resources professionals and industrial psychologists [108]. According to Human capital theory, Becker [109] proposes to invest in human capital is the key to increase employee profits and productivity, also the employee well-being, because that will lead to high performance in the organization. As a result, it can benefit both employees and organizations. Besides, the high cost of employee turnover, the organizations convinced that efforts should be made to retain, develop, and promote the employees. Hence, it becomes more and more important that employees learn to understand each other and work together effectively and harmoniously [40], [110], [111]. Therefore, [112] argues that increased employee involvement can increase satisfaction in an organization's processes and decisions. The author also noted that employee engagement and belongingness lead to greater employee motivation and at the same time strengthen the organization. Moreover, employee participation in problem-solving and decision making can lead to increased productivity, improved attitudes, and decreased absenteeism and employee turnover. Furthermore, changes in management systems and behaviour of senior managers and changes in organizational variables, such as the scale of benefits, employee participation, a work environment which may pose the value for the employee, and can reduce employee turnover [42], [113]. The organizations usually develop the skills of the employees and they often leave before making full use of their talents and their contributions to the organization, they exiting their organizations without a sufficient return on large investments that were made on them. Organizations need to bring the interest of their employees to make huge progress in their experience, which would enhance and increase creativity and increased profits [110], [114], [115].

The organization might improve the effectiveness of their employees in several ways. Could be through training programs, constant motivation in the workplace, employee empowerment, promotion and bonus programs [110]. The organizations had become more interested in avoiding employee turnover, and that could be through job training which would increase the performance and retaining employees also, coaching an intense task for a manager. Over time it could increase an employee's strengths, reduce weaknesses, and help the employee to realize his or her full potential, so that will be benefiting the employee, the manager, and the organization as a whole [30], [116], [117]. The managers could promote the identification of a company's goals and principles for employees through training programs to reduce employee turnover [118]. Employee dissatisfaction, absenteeism and turnover can be greatly reduced if employees are so well trained that they can feel instant satisfaction with a sense of accomplishment and knowledge that develops their capabilities [119]. According to [120] it is difficult to find and hire good, talented and valuable employees. Thus, employers are interested in retaining their current employees. Organizations generally try to find ways to create and expand job embeddedness which would increase retention rates and reduce costs related to recruitment, training, and employee turnover [121]. Moreover, the employees are highly critical for the organization's success, therefore; reducing turnover is a challenge to keep organizational costs under control [118], [122]. Organizations can reduce the costs of recruiting and training new employees through the retention of the existing employees in organizations [123]. Moreover, [124] have demonstrated the organization's specific benefits from employee training and development, including increased productivity, lower employee turnover, and greater efficiency, leading to financial benefits and less need for supervision.

Quality of Work Environment (QWE) is an environmental condition, but also how the physical working conditions contribute to a sense of efficiency, satisfaction, and productivity at work [125]. The origins of the QWE concept can be traced back to Scandinavia, where the "working environment" since the 1970s has largely replaced the narrower concept of "occupational health and safety", which was mainly associated with physical hazards and risks at work [41]. The work environment is a factor that influences an employee's decision to remain with the organization. Employees will remain in the organization even if they enjoy the work environment. Therefore, organizations must create a supportive work environment to retain skilled employees within the organization for the long term [126]. A good workplace is a place where employees and managers work together to continually improve and promote well-being that will general appreciation along in the organization [41]. Likewise, strong social relations in the work environment will increase employees' job satisfaction and productivity [127], [128]. To illustrate, social relationships create a sense of belonging and reduce the stress which induces employees to stay in the organization [129]. Further, greater job satisfaction can reduce employee turnover intention in the organization [30], [40]. Moreover, A positive work environment includes employee training and family-friendly policies [130]. Familyfriendly policies include flexibility in the workplace, such as when, where, and how an employee works, and this positively affects employees' decisions to stay [131]. Contrastively, negative environmental factors do not promote or train employees, which negatively affects the employees, and this would enhance their decision to leave the organization [130]. Organizations should avoid a negative working environment for employee job satisfaction. Thus, organizations need to maintain a suitable working environment to increase employee job satisfaction, which can lead to increased productivity that benefits both employees and the business [132]. Moreover, a good quality work environment is indicated by lower stress levels, a sense of gratitude from the leadership and the absence of threats [2], [133]. Besides, [41] has confirmed that the employees are likely to want to leave if they are not pertinent, believe that they do not receive enough important information promptly, stress and low job satisfaction. Therefore, the manager needs to focus on the work environment to allow the employee to work conducive, thus helping to unleash their capabilities. Failure to comply at any level can lead to low motivation and insufficient staff, resulting in poor performance and possibly affecting employee turnover in the organization [134], [135].

Another significant aspect, compatibility between individuals and their work environment increases the likelihood of job engagement [49]. Job engagement has been 
described by [136] as high energy, strong participation, and effectiveness. The organization's success depends on employee engagement. Employees have been shown to impact the organization in terms of productivity, level of motivation, profitability, and sustainability [137]. Employees show high energy by persevering under difficult circumstances and put all their efforts into their work. Strong participation is a feeling of inspiration, significance, enthusiasm, and effectiveness is the belief that employees can control their work. Employees feel more committed when they felt empowerment and support from the organization that would develop a more complete understanding of their organization [138]. Besides, the extent to which employees feel that their organization appreciates their contribution and cares about well-being can efficiently reduce their intention to quit [139]-[141]. Further, research has shown that engagement includes a sense of belonging and accomplishment, as well as employee satisfaction and efficiency [115], [142]. Thus, employees with high levels of engagement are less likely to leave their jobs [143]. Similarly, organizations that effectively implement an employee engagement approach can have significant competitive advantages [144], [145]. For example, these organizations may have a high level of employee retention and productivity [114], [146]. Besides, organizations seek to better understand their employees and how they think act and interact within organizations [110]. Moreover, organizations need to understand the process employees go through when they decide to leave in order to reduce the number of cases turnover [147]. However, it is believed that job involvement, job satisfaction, organizational attractiveness, organizational support, as well as many other variables, have a significant impact on the extent to which organizations can retain their talented employees [148]. Additionally, job involvement has recently been highlighted as an important element in the development of loyalty and attachment, which results in a decrease in the rate of turnover intentions. likewise, [149] indicated that job involvement is effective attitudes that affect employees' decisions, productivity and work-related decisions, which can affect the effectiveness of the organization. Job involvement depends on the work environment, such as organizational support, organizational attractiveness and pays satisfaction, which may decrease work tension and increase job satisfaction and minimize the turnover intention [15], [121]. Furthermore, Job involvement refers to the psychological connection of the employee with his job, such as interest and participation towards jobs. Besides, people who demonstrate active involvement in the work also consider their work an important part of their identity [150], [151]. Employee turnover is affected by job involvement. Higher job involvement reduces employee turnover [147].

In many previous studies, job satisfaction has been a predictor of many variables, including customer satisfaction, loyalty, performance, and commitment. In support, [152] points out, job satisfaction is an important part of an organization's behaviour and environment, while increasing the organization's overall productivity. Job satisfaction and pay satisfaction are among the motivational factors that influence employee satisfaction [15], [153], [154]. However, job satisfaction has a direct impact on the productivity and performance of organizations, as well as on employees' intention to remain in their organization [155]. Further, [156] to ensure success, the organization must focus on the needs of employees and implements employee retention strategies. In addition, implementing strategies would increase job satisfaction and that can diminish employment problems.

On the other hand, most scholars and professionals believe that external and internal rewards and benefits can increase organizational commitment and reduce employee turnover [122], [157]. For instance, the internal benefits such as increased sales, improved product quality, motivated employees, while the external benefits such as increased market share and improved image and reputation [158]. Moreover, [159] mentioned that both external and internal factors of employee retention were identified, which contributes to the accumulation of knowledge regarding employee retention. The authors note that monetary and nonmonetary rewards were used in motivation. Furthermore, [160] emphasized that human resource managers must be aware of what employees value to reduce their intention to leave and increase their retention. Therefore, Table II summarizes employee retention strategies.

TABLE II: EMPLOYEE RETENTION STRATEGIES

\begin{tabular}{ccc}
\multicolumn{3}{c}{ TABLE II: EMPLOYEE RETENTION STRATEGIES } \\
\hline \hline No & Strategy & Source \\
\hline 1 & Management & {$[42],[113]$} \\
2 & Training & {$[118],[124]$} \\
3 & Job Involvement & {$[15],[149]$} \\
4 & Job Satisfaction & {$[153],[155]$} \\
5 & Rewards and Benefits & {$[122],[159]$} \\
6 & Job Engagement & {$[3],[96]$} \\
7 & Work Environment & {$[2],[132]$} \\
8 & Employee Participation & {$[113],[136]$} \\
\hline \hline
\end{tabular}

\section{CONCLUSION}

The purpose of the research was to understand the causes of employee turnover and retention strategies for employees in the organization. Obviously, there are many reasons why an employee leaves their job, and some of these reasons are insufficient training or lack of feedback, work-related factors, lack of trust, high work stress, less challenging work, low job satisfaction, poor working environment, family pressure, low wages, a large work group, and poor leaders and managers.

Consequently, the organization must understand the needs of its employees, which will help organizations, adopt certain strategies to improve employee performance and reduce turnover. Therefore, there are several employee retention strategies, such as good management systems, provision of training, job involvement, job satisfaction, provision of rewards and benefits, high job engagement, good management systems and high employee participation.

Wherefore, that would ensure improved performance of individual employees and organizations. It is more effective for the human resource system to promote competence, motivation, and opportunities among the employees to create sustainable employee performance. 


\section{REFERENCES}

[1] A. Belete, "Turnover Intention Influencing Factors of Employees: An Empirical Work Review,” J. Entrep. Organ. Manag., vol. 07, no. 03, pp. 23-31, 2018, doi: 10.4172/2169-026X.1000253.

[2] N. E. Alias, S. Ismail, R. Othman, and W.-L. Koe, "Factors Influencing Turnover Intention in a Malaysian Manufacturing Company," KnE Soc. Sci., vol. 3, no. 10, p. 771, Oct. 2018, doi: 10.18502/kss.v3i10.3171.

[3] J. D. Smith, "Successful Strategies for Reducing Employee Turnover in the Restaurant Industry," 2018.

[4] A. Hussein Alkahtani, "Investigating Factors that Influence Employees' Turnover Intention: A Review of Existing Empirical Works," Int. J. Bus. Manag., vol. 10, no. 12, p. 152, 2015, doi: 10.5539/ijbm.v10n12p152.

[5] C. A. Al Mamun and M. N. Hasan, "Factors affecting employee turnover and sound retention strategies in business organization: A conceptual view," Probl. Perspect. Manag., vol. 15, no. 1, pp. 63-71, 2017, doi: 10.21511/ppm.15(1).2017.06.

[6] A. F. Schlechter, C. Syce, and M. Bussin, "Predicting voluntary turnover in employees using demographic characteristics: A South African case study," Acta Commer., vol. 16, no. 1, 2016, doi: 10.4102/ac.v16i1.274.

[7] A. A. Al-suraihi, N. A. Wahab, and W. A. Al-suraihi, "The Effect of Entrepreneurship Orientation on Entrepreneurial Intention among Undergraduate Students in Malaysia," Asian J. Entrep., vol. 1, no. 3, pp. 14-25, 2020, doi: http://myjms.moe.gov.my/index.php/aje.

[8] Minister of Human Resources Malaysia, "National Employment Returns Report 2016," 2016.

[9] S. Ilmi, Habizah, H. Xue Qi, M. Gheda, and M. Liza, "Employee Turnover of Quantity Surveying Firms in Malaysia," IOP Conf. Ser. Mater. Sci. Eng., vol. 636, no. 1, 2019, doi: 10.1088/1757899X/636/1/012020

[10] W. H. Mobley, "Employee Turnover: Causes, Consequences, and Control”, Price Ind. Labor Relations Rev., vol. 36, no. 3, pp. 506-507, 1983.

[11] A. L. Hakim, Sudarmiatin, and Sutrisno, "The Effect of Work Stress on Turnover Intention with Work Satisfaction and Commitment as Intervening Variable (Study at PT Infomedia Solusi Humanika in Malang)," Eur. J. Bus. Manag., vol. 10, no. 12, pp. 85-94, 2018, [Online]. Available: www.iiste.org.

[12] L. Branham, "How to Recognize the Subtle Signs," 7 Reason. employees leave, vol. 27, no. 6, pp. 1-8, 2005.

[13] S. Alaarj, Z. Abidin-Mohamed, and U. S. B. A. Bustamam, "Mediating Role of Trust on the Effects of Knowledge Management Capabilities on Organizational Performance," Procedia - Soc. Behav. Sci., vol. 235, no. October, pp. 729-738, 2016, doi: 10.1016/j.sbspro.2016.11.074.

[14] M. Alhamwan and N. Mat., "Antecedents of Turnover Intention Behavior among Nurses: A Theoretical Review,” J. Manag. Sustain., vol. 5, no. 1, pp. 84-89, 2015, doi: 10.5539/jms.v5n1p84.

[15] M. A. Alshammari, B. A. A. L. Qaied, H. Al-Mawali, and M. Matalqa, "What drives employee's involvement and turnover intentions: Empirical investigation of factors influencing employee involvement and turnover intentions?", Int. Rev. Manag. Mark., vol. 6, no. 2, pp. 298-306, 2016.

[16] P. E. Spector et al., "Cross-national differences in relationships of work demands, job satisfaction, and turnover intentions with work-family conflict," Pers. Psychol., vol. 60, no. 4, pp. 805-835, 2007, doi: 10.1111/j.1744-6570.2007.00092.x.

[17] A. R. Jaffari, J. Aziz, Z. Hussain, N. Akhtar, and K. Ur-Rehman, "Prime and sub-prime factors of employee voluntary turnover in boom phase of industry: Empirical evidence from banking sector of Pakistan,” African J. Bus. Manag., vol. 5, no. 15, pp. 6408-6414, Aug. 2011, doi: 10.5897/AJBM10.1556.

[18] W. H. Mobley, "Intermediate linkages in the relationship between job satisfaction and employee turnover," J. Appl. Psychol., vol. 46, no. 3, pp. 237-240, 1977, doi: 10.1037/0021-9010.62.2.237.

[19] I. Ahmed and N. A. Kolachi, "Employee Payroll and Training Budget: Case Study Of A Non-Teaching Healthcare Organization,” J. Bus Econ. Res., vol. 11, no. 5, p. 229, Apr. 2013, doi: 10.19030/jber.v11i5.7838.

[20] Y. Chen, C. Wang, and W. Cheng, "Structural investigation of the relationship between working satisfaction and employee turnover," J. Hum. ..., vol. 6, no. 1, pp. 41-50, 2010.

[21] K. Shahzad, U. Rehman, I. Shad, A. Gul, and M. Amnulah Khan, "Work-life policies and job stress as determinants of turnover intentions of customer service representatives in Pakistan," Eur. J. Soc. Sci., vol. 19, no. 3, pp. 403-411, 2011.
[22] I. Ibrahim, A. B. Melhem, and K. Ali, "The Impact of Challenging Work on Employee's Retention in the Manufacturing Industry in Klang Valley,” Int. J. Psychol. Cogn. Sci., vol. 5, no. 1, pp. 1-8, 2019.

[23] I. Mohammad and A. Jahangir, "Factors influencing Intention to Quit or Stay in Jobs: An Empirical Study on selected sectors in Bangladesh,' Stamford J. Bus. Stud., vol. 6, no. 1, pp. 142-164, 2014, [Online]. Available:

https://www.researchgate.net/publication/292963289_Factors_influen cing_Intention_to_Quit_or_Stay_in_Jobs_An_Empirical_Study_on_s elected_sectors_in_Bangladesh.

[24] N. S. Govindarajo, M. Dileep Kumar, and S. S. Ramulu, "Why workers disengage? Factors from 'head' or 'heart' to be tagged on?," Asian Soc. Sci., vol. 10, no. 17, pp. 108-119, 2014, doi: 10.5539/ass.v10n17p108

[25] W. (Amy) Tian-Foreman, "Job satisfaction and turnover in the Chinese retail industry,” Chinese Manag. Stud., vol. 3, no. 4, pp. 356-378, Oct. 2009, doi: 10.1108/17506140911007503.

[26] W. A. Al-Suraihi, A. H. Yusuf, and A.-H. A. Al-Suraihi, "The Effect of Job Characteristics and Perceived Organizational Support on Employee Turnover Intention in the Retail Sector in Malaysia,' Int. J. Bus. Technol. Manag., vol. 2, no. 3, pp. 118-125, Jun. 2020, [Online] Available: http://myjms.mohe.gov.my/index.php/ijbtm/article/view/11146.

[27] A. Asegid, T. Belachew, and E. Yimam, "Factors Influencing Job Satisfaction and Anticipated Turnover among Nurses in Sidama Zone Public Health Facilities, South Ethiopia," Nurs. Res. Pract., vol. 2014, pp. 1-26, 2014, doi: 10.1155/2014/909768

[28] C. Long and P. Perumal, "Examining the Impact of Human Resource Management Practices on Employees' Turnover Intention,” Int. J. Bus. Soc., vol. 15, no. 1, pp. 111-126, 2014.

[29] A. Abdullah, A. A. Bilau, A. M. Ajagbe, and S. A. Bustani, "Small and medium sized construction firms job satisfaction and performance evaluation in Nigeria," Int. Dr. Fellowsh. Res. Univ. Grant, 2011

[30] T. C. Keng, N. Nur, A. Mohamed, and Y. K. Ching, "Strategies of quantity surveying firms to reduce turnover intention," Int. J. Eng. Technol., vol. 8, pp. 1-4, 2019

[31] M. W. Akhtar, A. Shabir, M. S. Safdar, and M. S. Akhtar, "Impact of Emotional Intelligence on Turnover Intentions: The Role of Organizational Commitment and Perceive Organizational Support,” J. Account. Mark., vol. 06, no. 04, 2017, doi: 10.4172/21689601.1000259

[32] B. C. Holtom and T. C. Burch, "A model of turnover-based disruption in customer services," Hum. Resour. Manag. Rev., vol. 26, no. 1, pp. 25-36, 2016, doi: 10.1016/j.hrmr.2015.09.004.

[33] S. G. Green, S. E. Anderson, and S. L. Shivers, "Demographic and organizational influences on leader-member exchange and related work attitudes," Organ. Behav. Hum. Decis. Process., vol. 66, no. 2, pp. 203 214, May 1996, doi: 10.1006/obhd.1996.0049.

[34] S. W. J. Kozlowski and B. S. Bell, "Work Groups and Teams in Organizations," in Handbook of Psychology, Hoboken, NJ, USA: John Wiley \& Sons, Inc., 2003, pp. 333-375.

[35] A. O. Banwo and J. Du, "When the good outweighs the bad organizational citizenship behaviour (OCB) in the workplace," Hum. Resour. Dev. Int., vol. 23, no. 1, pp. 88-97, 2020, doi 10.1080/13678868.2018.1449546.

[36] J. P. Hausknecht and C. O. Trevor, "Collective turnover at the group, unit, and organizational levels: Evidence, issues, and implications," J. Manage., vol. 37, no. 1, pp. 352-388, Jan. 2011, doi: $10.1177 / 0149206310383910$

[37] J. P. Hausknecht, C. O. Trevor, and M. J. Howard, "Unit-Level Voluntary Turnover Rates and Customer Service Quality: Implications of Group Cohesiveness, Newcomer Concentration, and Size,” J. Appl. Psychol., vol. 94, no. 4, pp. 1068-1075, 2009, doi: 10.1037/a0015898.

[38] M. Thomas, V. Kohli, and J. Choi, "Correlates of job burnout among human services workers: Implications for workforce retention," $\mathrm{J}$ Sociol. Soc. Welf., vol. 41, no. 4, pp. 69-90, 2014, Accessed: Apr. 03, 2020. [Online]. Available: https://scholarworks.wmich.edu/jsswAvailableat:https://scholarworks. wmich.edu/jssw/vol41/iss4/5.

[39] M. Mitchell and C. D. Zatzick, "Skill underutilization and collective turnover in a professional service firm," J. Manag. Dev., vol. 34, no. 7, pp. 787-802, Jul. 2015, doi: 10.1108/JMD-09-2013-0112.

[40] P. Prasetio, A. Partono, and P. Wulansari, "The Mediation of Job Satisfaction in the Relation of Work Stress and Turnover Intention in Hotel Industry," 1st Int. Conf. Econ. Business, Entrep. Financ., vol. 65 , no. 2352-5428, pp. 608-612, 2019

[41] R. Markey, K. Ravenswood, and D. J. Webber, "Quality of work environment and quitting intention: A dilemma," New Zeal. J. Employ. Relations, vol. 40, no. 1, pp. 35-52, 2015, [Online]. Available: http://ezproxy.library.ubc.ca/login?url=https://search.proquest.com/do cview/1686086241 ?accountid=14656\%0Ahttp://gw2jh3xr2c.search.se 
rialssolutions.com/directLink?\&atitle=Quality+of+work+environment + and+quitting+intention $\% 3 \mathrm{~A}+\mathrm{A}+$ dilemma\&author=Markey $\% 2 \mathrm{C}+\mathrm{Ra}$ ym.

[42] A. Nanda, M. Soelton, S. Luiza, and E. T. P. Saratian, "The Effect of Psychological Work Environment and Work Loads on Turnover Interest, Work Stress as an Intervening Variable," vol. 120, no. Icmeb 2019, pp. 225-231, 2020, doi: 10.2991/aebmr.k.200205.040.

[43] A. A. Soomro, R. J. Breitenecker, and S. A. M. Shah, "Relation of work-life balance, work-family conflict, and family-work conflict with the employee performance-moderating role of job satisfaction," South Asian J. Bus. Stud., vol. 7, no. 1, pp. 129-146, Mar. 2018, doi: 10.1108/SAJBS-02-2017-0018.

[44] C. Kerdpitak and K. Jermsittiparsert, "The effects of workplace stress, work-life balance on turnover intention: An empirical evidence from pharmaceutical industry in Thailand," Syst. Rev. Pharm., vol. 11, no. 2, pp. 586-594, 2020, doi: 10.5530/srp.2020.2.86.

[45] I. H. Mohd, M. Mohd Shah, and N. S. Z. Zailan, "How Work Environment affects the Employee Engagement in a Telecommunication Company," in International Conference on Business and Economics, Nov. 2016, pp. 418-426, doi: 10.15405/epsbs.2016.11.02.37

[46] H. N. K. Giao, B. N. Vuong, D. D. Huan, H. Tushar, and T. N. Quan, "The Effect of Emotional Intelligence on Turnover Intention and the Moderating Role of Perceived Organizational Support: Evidence from the Banking Industry of Vietnam," Sustainability, vol. 12, no. 5, p. 1857, Mar. 2020, doi: 10.3390/su12051857.

[47] Y. M. Yunus, K. Idris, A. A. Rahman, and H. I. Lai, "The role of Quality of Nursing Work Life and Turnover Intention in Primary Healthcare Services among Registered Nurses in Selangor," Int. J. Acad. Res. Bus. Soc. Sci., vol. 7, no. 6, pp. 1201-1213, 2017, doi: 10.6007/ijarbss/v7-i6/3353

[48] G. K. Özbağ and G. Ç. Ceyhun, "Does Job Satisfaction Mediate the Relationship between Work-family Conflict and Turnover? A Study of Turkish Marine Pilots," Procedia - Soc. Behav. Sci., vol. 140, pp. $643-$ 649, 2014, doi: 10.1016/j.sbspro.2014.04.485

[49] S. Harrison and P. A. Gordon, "Misconceptions of Employee Turnover: Evidence-Based Information For The Retail Grocery Industry," J. Bus. Econ. Res., vol. 12, no. 2, p. 145, 2014, doi: 10.19030/jber.v12i2.8528

[50] M. Yu and H. Lee, "Impact of resilience and job involvement on turnover intention of new graduate nurses using structural equation modeling," Japan J. Nurs. Sci., vol. 15, no. 4, pp. 351-362, 2018, doi $10.1111 /$ jjns. 12210.

[51] J. N. Scanlan and M. Still, "Relationships between burnout, turnover intention, job satisfaction, job demands and job resources for mental health personnel in an Australian mental health service," BMC Health Serv. Res., vol. 19, no. 1, p. 62, Dec. 2019, doi: 10.1186/s12913-0183841-z.

[52] C. Huang, K. Wu, and Y. Zhang, "Understanding precedents for frontline employee turnover in luxury hotels: Emotional intelligence as a unifying factor,” J. Hum. Resour. Hosp. Tour., vol. 18, no. 1, pp. 26 46, 2019, doi: 10.1080/15332845.2019.1526504.

[53] W. Rahman and Z. Nas, "Employee development and turnover intention: Theory validation,” Eur. J. Train. Dev., vol. 37, no. 6, pp. 564-579, 2013, doi: 10.1108/EJTD-May-2012-0015.

[54] C. S. Reina, K. M. Rogers, S. J. Peterson, K. Byron, and P. W. Hom, "Quitting the Boss? The Role of Manager Influence Tactics and Employee Emotional Engagement in Voluntary Turnover," J Leadersh. Organ. Stud., vol. 25, no. 1, pp. 5-18, 2018, doi: $10.1177 / 1548051817709007$.

[55] Omer Azam, Hafiz Ghufran Ali Khan, A. Khan, and Abdul Zahid Khan, "Impact of Passive Leadership on Organizational Citizenship Behavior and Turnover Intentions; Mediating Effect of Organizational Interpersonal Trust," Rev. Econ. Dev. Stud., vol. 5, no. 4, pp. 663-674, 2019, doi: 10.26710/reads.v5i4.663.

[56] O. Brinck and H. Larsson, "Workplace Values, Sustainable Employment and Turnover Intention: a Generational Perspective,' Umeå Univ., 2019.

[57] C. S. Long, L. Y. Thean, W. Khairuzzaman, W. Ismail, and A. Jusoh, "Leadership styles and employees' turnover intention: Exploratory study of academic staff in a Malaysian college," World Appl. Sci. J., vol. 19, no. 4, pp. 575-581, 2012, doi: 10.5829/idosi.wasj.2012.19.04.155

[58] L. K. Ladelsky, "Causes affecting voluntary turnover in IT sector. Review of some empirical studies," vol. 6, pp. 102-114, 2013.

[59] M. Matsuo, "Human resource development programs for knowledge transfer and creation: the case of the Toyota Technical Development Corporation,” J. Knowl. Manag., vol. 19, no. 6, pp. 1186-1203, 2015, doi: 10.1108/JKM-03-2015-0108.

[60] L. Duxbury and M. Halinski, "Dealing with the 'Grumpy Boomers': Re-engaging the disengaged and retaining talent," J. Organ. Chang.
Manag., vol. 27, no. 4, pp. 660-676, 2014, doi: 10.1108/JOCM-052014-0106.

[61] G. Hofstede, Cultures and organizations: software of the mind. London; New York: McGraw-Hill, 1991.

[62] M. Girish, "Exploring the Term 'Employee Turnover,"” J. Adv. Sch. Res., vol. II, no. Ii, pp. 1-7, 2011.

[63] L. Kessler, "the Effect of Job Satisfaction on It Employees Turnover Intention," Ann. Univ. Oradea, pp. 1028-1039, 2014.

[64] S. Kim, L. Tam, J. N. Kim, and Y. Rhee, "Determinants of employee turnover intention: Understanding the roles of organizational justice, supervisory justice, authoritarian organizational culture and organization-employee relationship quality," Corp. Commun., vol. 22 no. 3, pp. 308-328, 2017, doi: 10.1108/CCIJ-11-2016-0074.

[65] H. Roshidi, "Factors Influencing Turnover Intention Among Technical Employees in Information Technology Organization: A Case of XYZ (M) Sdn. Bhd.," Int. J. Arts Commer., vol. 3, no. 9, pp. 120-137, 2014

[66] B. K. Lee, D. K. Seo, J. T. Lee, A. R. Lee, H. N. Jeon, and D. U. Han, "Impact of work environment and work-related stress on turnover intention in physical therapists," J. Phys. Ther. Sci., vol. 28, no. 8, pp 2358-2361, 2016, doi: 10.1589/jpts.28.2358.

[67] M. Coetzee and D. Pauw, "Staff Perception of Leader Emotional Competency as a Predictor of Satisfaction with Retention Factors," J. Psychol. Africa, vol. 23, no. 2, pp. 177-185, Jan. 2013, doi 10.1080/14330237.2013.10820613.

[68] E. MJ, A. EU, and P. NM, "Impact of Workplace Environment on Health Workers," Occup. Med. Heal. Aff., vol. 05, no. 02, 2017, doi: 10.4172/2329-6879.1000261.

[69] N. Kamarulzaman, N. Z. Zulkeflee, H. A. Hamid, N. Sahari, and F. N. A. Halim, "Exploring the Factors of High Turnover in Retail Industry in Negeri Sembilan,” Procedia Econ. Financ., vol. 31, no. 15, pp. 896902, 2015, doi: 10.1016/S2212-5671(15)01187-9.

[70] L. K. Siew, "Analysis of the Relationship between Leadership Styles and Turnover Intention within Small Medium Enterprise in Malaysia,' J. Arts Soc. Sci., vol. 1, no. 1, pp. 1-11, 2017.

[71] M. Falahat, S. K. Gee, and C. M. Liew, "A model for turnover intention: Banking industry in Malaysia," Asian Acad. Manag. J., vol. 24, pp. 79-91, 2019, doi: 10.21315/aamj2019.24.s2.6.

[72] C. D. Ainer, C. Subramaniam, and L. Arokiasamy, "Determinants of Turnover Intention in the Private Universities in Malaysia: A Conceptual Paper," SHS Web Conf., vol. 56, p. 03004, 2018, doi: $10.1051 /$ shsconf/20185603004

[73] M. A. Demircioglu and E. Berman, "Effects of the Innovation Climate on Turnover Intention in the Australian Public Service," Am. Rev. Public Adm., 2018, doi: 10.1177/0275074018808914.

[74] A. Mohsin, J. Lengler, and R. Aguzzoli, "Staff turnover in hotels: Exploring the quadratic and linear relationships," Tour. Manag., vol. 51, pp. 35-48, 2015.

[75] A. Beato, "Effective Strategies Employed by Retail Store Leaders to Reduce Employee Turnover," Walden Univ., 2017, doi: ProQuest 10278363

[76] A. Noor, Y. Zainuddin, S. K. Panigrahi, and F. binti T. Rahim, "Investigating the Relationship among Fit Organization, Organization Commitment and Employee's Intention to Stay: Malaysian Context," Glob. Bus. Rev., 2018, doi: 10.1177/0972150918755896.

[77] G. Zaman, N. Ali, and N. Ali, "Impact of Organizational justice on employees outcomes: An Empirical Evidence," Abasyn J. Soc. Sci., vol. 3, no. 1, pp. 44-53, 2010.

[78] M. Noh, H. Jang, and B. J. Choi, "Organisational justice, emotional exhaustion, and turnover intention among Korean IT professionals: Moderating roles of job characteristics and social support," Int. J. Technol. Manag., vol. 79, no. 3-4, pp. 322-344, 2019, doi: 10.1504/ijtm.2019.10021163.

[79] B. I. Van der Heijden, M. C. Peeters, P. M. Le Blanc, and J. W. M. Van Breukelen, "Job characteristics and experience as predictors of occupational turnover intention and occupational turnover in the European nursing sector,” J. Vocat. Behav., vol. 108, no. June, pp. 108120, Oct. 2018, doi: 10.1016/j.jvb.2018.06.008.

[80] J. Bersin, "Employee Retention Now a Big Issue: Why the Tide has Turned," Bersin by Deloitte, no. 16 August, pp. 1-4, 2013.

[81] A. Dube, Eric Freeman, and M. Reich, "Employee Replacement Costs," Inst. Res. Labor Employment, UC Berkeley, no. 201, 2010.

[82] K. Brzezinski, Why employees stay: A quantitative study of retention. Edgewood College, 2014.

[83] B. Meaghan and N. Stovel, "Voluntary turnover: Knowledge management - friend or foe?", J. Intellect. Cap., vol. 3, no. 3, pp. 303 322, 2002, doi: 10.1108/14691930210435633.

[84] H. A. Sullenger, "How Corporate Trainers Get Groupies: A Q methodology Study of Viewpoints on Why Trainees Seek out the Same Corporate Trainer for Additional Training," 2019. 
[85] R. A. Hashim and M. A. Mohamad Nor, "Employer branding and employee engagement of furniture retailer in Klang Valley," SHS Web Conf., vol. 56, p. 02003, 2018, doi: 10.1051/shsconf/20185602003.

[86] G. C. W. Gim, N. M. Desa, and T. Ramayah, "Competitive Psychological Climate and Turnover Intention with the Mediating Role of Affective Commitment," Procedia - Soc. Behav. Sci., vol. 172, pp. 658-665, 2015, doi: 10.1016/j.sbspro.2015.01.416.

[87] Q. Iqbal, N. Hazlina Ahmad, and S. Akhtar, "The Mediating Role of Job Embeddedness Fit: Perceived Job Characteristics and Turnover Intention in the Services Sector," Lahore J. Bus., vol. 6, no. 1, pp. 7192, 2017, doi: 10.35536/ljb.2017.v6.i1.a4.

[88] M. J. Burnett, "Strategies to Reduce Employee Turnover in the Durable Goods Industry," ProQuest Diss. Theses, p. 166, 2018, [Online]. Available: https://search.proquest.com/docview/2103316508?accountid=17242.

[89] A. L. Heavey, J. A. Holwerda, and J. P. Hausknecht, "Causes and consequences of collective turnover: A meta-analytic review," J. Appl. Psychol., vol. 98, no. 3, pp. 412-453, 2013, doi: 10.1037/a0032380.

[90] G. Tumwesigye, "The relationship between perceived organisational support and turnover intentions in a developing country: The mediating role of organisational commitment," African J. Bus. Manag., vol. 4, no. 6, pp. 942-952, 2010.

[91] Z. Ton and R. S. Huckman, "Managing the impact of employee turnover on performance: The role of process conformance," Organ Sci., vol. 19, no. 1, pp. 56-68, 2008, doi: 10.1287/orsc.1070.0294.

[92] R. F. Hurley and H. Estelami, "An exploratory study of employee turnover indicators as predictors of customer satisfaction," J. Serv. Mark., vol. 21, no. 3, pp. 186-199, May 2007, doi $10.1108 / 08876040710746543$.

[93] M. Tapola, "Effects of employee turnover on service quality and customer satisfaction in contact centers Title of thesis Effects of employee turnover on service quality and customer satisfaction in contact centers," Aalto Univ. Sch. Bus., pp. 1-125, 2016, [Online]. Available:

https://pdfs.semanticscholar.org/f226/946a12538471762d7d399939eb eed0effacf.pdf.

[94] W. A. Al-Suraihi, A.-H. A. Al-Suraihi, I. Ibrahim, A. Al-Tahitah, and M. Abdulrab, "The Effect of Customer Relationship Management on Consumer Behavior: A Case of Retail Industry in Malaysia," Int. J. Manag. Hum. Sci., vol. 4, no. 3, pp. 32-40, 2020.

[95] C. Hare, "The food-shopping experience: a satisfaction survey of older Scottish consumers," Int. J. Retail Distrib. Manag., vol. 31, no. 5, pp. 244-255, May 2003, doi: 10.1108/09590550310472415.

[96] M. Kang and M. Sung, "To leave or not to leave: the effects of perceptions of organizational justice on employee turnover intention via employee-organization relationship and employee job engagement," J. Public Relations Res., vol. 31, no. 5-6, pp. 152-175, 2019, doi: 10.1080/1062726X.2019.1680988.

[97] Y. Tsai and S.-W. Wu, "The relationships between organisational citizenship behaviour, job satisfaction and turnover intention," J. Clin. Nurs., vol. 19, no. 23-24, pp. 3564-3574, Dec. 2010, doi: 10.1111/j.1365-2702.2010.03375.x.

[98] K. Woods, "Exploring the relationship between employee turnover rate and customer satisfaction levels," Exch., vol. 4, no. 1, pp. 18-28, 2015.

[99] A. A. H. Ebtsam, "Relationship between ethical work climate and nurses' perception of organizational support, commitment, job satisfaction and turnover intent," Nurs. Ethics, pp. 1-16, 2015.

[100]U. Saraih, A. Zuraini Zin Aris, and R. Ahmad, "Factors Affecting Turnover Intention Among Academician in the Malaysian Highe Educational Institution,” Rev. Integr. Bus. Econ. Res., vol. 6, no. 1, pp. $1-15,2016$.

[101]K. K. Michele, M. C. Andrews, D. L. Van Rooy, R. Chris Steilberg, and S. Cerrone, "Sure everyone can be replaced ... But at what cost? Turnover as a predictor of unit-level performance," Acad. Manag. J. vol. 49, no. 1, pp. 133-144, 2006, doi: 10.5465/amj.2006.20785670.

[102]J. C. McElroy, P. C. Morrow, and S. N. Rude, "Turnover and organizational performance: A comparative analysis of the effects of voluntary, involuntary, and reduction-in-force turnover," J. Appl. Psychol., vol. 86, no. 6, pp. 1294-1299, 2001, doi: 10.1037/00219010.86.6.1294.

[103]S. Banu, G. Krishnapillai, and P. Padmashantini, "Customer Retention Practices Among the Major Retailers in Malaysia," Int. J. Acad. Res. Bus. Soc. Sci., vol. 2, no. 6, pp. 157-166, 2012.

[104]S. Benn, S. T. T. Teo, and A. Martin, "Employee participation and engagement in working for the environment," Pers. Rev., vol. 44, no. 4, pp. 492-510, Jun. 2015, doi: 10.1108/PR-10-2013-0179.

[105]J. M. Inabinett and J. M. Ballaro, "Developing an organization by predicting employee retention by matching corporate culture with employee's values: A correlation study.," Organ. Dev. J., vol. 32, no. 1, pp. 55-74, 2014
[106]O. S. Shaban, Z. Al-Zubi, N. Ali, and A. Alqotaish, "The Effect of Low Morale and Motivation on Employees' Productivity \& Competitiveness in Jordanian Industrial Companies,” Int. Bus. Res., vol. 10, no. 7, p. 1, 2017, doi: 10.5539/ibr.v10n7p1.

[107]N. Rathi and K. Lee, "Retaining talent by enhancing organizational prestige," Pers. Rev., vol. 44, no. 4, pp. 454-469, Jun. 2015, doi: 10.1108/PR-05-2013-0070.

[108]A. Raj and A. Arokiasamy, "A Qualitative Study on Causes and Effects of Employee Turnover in the Private Sector in Malaysia," Middle-East J. Sci. Res. Manag. Soc. Sci. Plaza Teh Teng Seng. Soc. Sci., vol. 16, no. $2, \quad$ pp. 1532-1541, 2013, doi 10.5829/idosi.mejsr.2013.16.11.12044.

[109]G. S. Becker, "Investment in Human Capital: A Theoretical Analysis," J. Polit. Econ., vol. 70, no. 5, Part 2, pp. 9-49, 1962, doi $10.1086 / 258724$

[110]S. Osborne and M. S. Hammoud, "Effective Employee Engagement in the Workplace," Int. J. Appl. Manag. Technol., vol. 16, no. 1, pp. 5067, 2017, doi: 10.5590/IJAMT.2017.16.1.04

[111]M. A. Sanjeev, "Impact of Individual and Employment Variable on Job Satisfaction \& Turnover Intention among Sales and Marketing Professionals," Procedia Comput. Sci., vol. 122, pp. 55-62, 2017, doi: 10.1016/j.procs.2017.11.341

[112]K. Carleton, "How to motivate and retain knowledge workers in organizations: A review of the literature," Int. J. Manag., vol. 28, no. 2, p. 459,2011

[113]A. M. Mosadeghrad, "Quality of working life: An antecedent to employee turnover intention,” Int. J. Heal. Policy Manag., vol. 1, no. 1, pp. 43-50, 2013, doi: 10.15171/ijhpm.2013.07.

[114]V. Jagun, "An Investigation into the High Turnover of Employees within the Irish Hospitality Sector, Identifying What Methods of Retention Should Be Adopted. A Dissertation submitted in partial fulfilment for the MA in Human Resource Management," 2015.

[115]B. J. Osabiya, "The effect of employees motivation on organizational performance," J. Public Adm. Policy Res., vol. 7, no. 4, pp. 62-75, 2015, doi: 10.5897/jpapr2014.0300.

[116]J. Afsana, F. Afrin, and T. Tarannum, "Effect of Training on Employee Performance: An Empirical Study on Telecommunication Industry in Bangladesh,” J. Bus. Technol., vol. 10, no. 2, pp. 67-80, 2016, doi 10.3329/jbt.v10i2.29468

[117]J. W. Pfeiffer, 1990 annual, developing human resources, First University Associates, San Diego, 1990.

[118]K. Jehanzeb, A. Rasheed, and M. F. Rasheed, "Organizational Commitment and Turnover Intentions: Impact of Employee's Training in Private Sector of Saudi Arabia," Int. J. Bus. Manag., vol. 8, no. 8, p. p79, Mar. 2013, doi: 10.5539/ijbm.v8n8p79.

[119]M. E. Motlokoa, L. P. Sekantsi, and R. P. Monyolo, "The Impact of Training on Employees' Performance: The Case of Banking Sector in Lesotho," Int. J. Hum. Resour. Stud., vol. 8, no. 2, p. 16, Mar. 2018 , doi: 10.5296/ijhrs.v8i2.12812.

[120]N. Barkhuizen, P. Mogwere, and N. Schutte, "Talent management, work engagement and service quality orientation of support staff in a higher education institution," Mediterr. J. Soc. Sci., vol. 5, no. 4, pp. 69-77, 2014, doi: 10.5901/mjss.2014.v5n4p69.

[121]S. Marasi, S. S. Cox, and R. J. Bennett, "Job embeddedness: is it always a good thing?,” J. Manag. Psychol., vol. 31, no. 1, pp. 141-153, 2016 , doi: 10.1108/JMP-05-2013-0150.

[122]S. Nazir, A. Shafi, W. Qun, N. Nazir, and Q. D. Tran, "Influence of organizational rewards on organizational commitment and turnover intentions," Empl. Relations, vol. 38, no. 4, pp. 596-619, 2016, doi: 10.1108/ER-12-2014-0150.

[123]R. J. Laudicina, T. C. Moon, S. Beck, and J. C. Morgan, "Retaining experts: retention incentives of clinical laboratory professionals.," Clin. Lab. Sci., vol. 27, no. 3, pp. 150-161, 2014, doi 10.29074/ascls.27.3.150

[124]S. K. Divya and S. Gomathi, "Effective Work Place Training: A Jump Starter to Organizational Competitive Advantage through Employee Development," Mediterr. J. Soc. Sci., vol. 6, no. 3, pp. 49-53, May 2015, doi: 10.5901/mjss.2015.v6n3p49

[125]A. Raziq and R. Maulabakhsh, "Impact of Working Environment on Job Satisfaction," Procedia Econ. Financ., 2015, doi: 10.1016/s22125671(15)00524-9.

[126]P. Bibi, A. Ahmad, and A. H. A. Majid, "The impact of training and development and supervisors support on employees retention in academic institutions in Pakistan: The moderating role of the work environment," Gadjah Mada Int. J. Bus., vol. 20, no. 1, pp. 113-131, 2018, doi: $10.22146 /$ gamaijb.24020.

[127] W. F. W. Yusoff, T. S. Kian, and M. T. M. Idris, "Herzberg' s TwoFactor Theory on Work Motivation: Does it Works for Todays Environment ?," Glob. J. Commer. \&Managment Perspect., vol. 2, no. 5, pp. 18-22, 2013. 
[128]Y. Akgunduz and G. Eryilmaz, "Does turnover intention mediate the effects of job insecurity and co-worker support on social loafing?", Int J. Hosp. Manag., vol. 68, no. March 2017, pp. 41-49, 2018, doi: 10.1016/j.ijhm.2017.09.010.

[129]K. Haldorai, W. G. Kim, S. G. Pillai, T. (Eliot) Park, and K. Balasubramanian, "Factors affecting hotel employees' attrition and turnover: Application of pull-push-mooring framework,” Int. J. Hosp. Manag., vol. 83, no. October 2018, pp. 46-55, 2019, doi 10.1016/j.ijhm.2019.04.003.

[130]J. Wynen and S. Op de Beeck, "The Impact of the Financial and Economic Crisis on Turnover Intention in the U.S. Federal Government," Public Pers. Manage., vol. 43, no. 4, pp. 565-585, Dec. 2014, doi: 10.1177/0091026014537043.

[131]K. Bin Bae and D. Goodman, "The Influence of Family-Friendly Policies on Turnover and Performance in South Korea," Public Pers. Manage., vol. 43, no. 4, pp. 520-542, Dec. 2014, doi $10.1177 / 0091026014536055$

[132]T. Lovick-mcdaniel, "Nonmonetary Strategies to Increase Employee Job Satisfaction in Nonprofit Organizations," WALDEN Diss. Dr. Stud., 2019.

[133]R. Markey, K. Ravenswood, and D. J. Webber, "The impact of the quality of the work environment on employees' intention to quit,' Work. Pap., 2012.

[134]Y. Badrianto and M. Ekhsan, "Effect of Work Environment and Job Satisfaction on Employee Performance in Pt. Nesinak Industries,' Manag. Account., vol. 2, no. 1, pp. 85-91, 2020, [Online]. Available: http://e-journal.stie-kusumanegara.ac.id.

[135]S. Pawirosumarto, P. K. Sarjana, and R. Gunawan, "The effect of work environment, leadership style, and organizational culture towards job satisfaction and its implication towards employee performance in Parador hotels and resorts, Indonesia,” Int. J. Law Manag., vol. 59, no. 6, pp. 1337-1358, 2017, doi: 10.1108/IJLMA-10-2016-0085.

[136] S. R. Sardeshmukh, D. Sharma, and T. D. Golden, "Impact of telework on exhaustion and job engagement: a job demands and job resources model," New Technol. Work Employ., vol. 27, no. 3, pp. 193-207, Nov. 2012, doi: 10.1111/j.1468-005X.2012.00284.x.

[137]P. Nidan, "To study the impact of employee engagement on employee productivity and motivational level of employee in retail sector," IOSR J. Bus. Manag., no. e-ISSN: 2278-487X, pp. 41-47, 2016, [Online]. Available: www.iosrjournals.org.

[138]L. Mory, B. W. Wirtz, and V. Göttel, "Corporate social responsibility strategies and their impact on employees' commitment," J. Strateg. Manag., vol. 9, no. 2, pp. 172-201, May 2016, doi: 10.1108/JSMA-122014-0097.

[139]K. Nadeem, M. A. Khan, N. Imtiaz, and Y. Iftikhar, "Turnover Intention and Perceived Organizational Support; Mediating Role of Work Engagement and Organizational Commitment,” Eur. Sci. J. ESJ, vol. 15, no. 10, pp. 222-236, 2019, doi 10.19044/esj.2019.v15n10p222.

[140]R. Gigliotti, J. Vardaman, D. R. Marshall, and K. Gonzalez, "The Role of Perceived Organizational Support in Individual Change Readiness,' J. Chang. Manag., vol. 19, no. 2, pp. 86-100, 2019, doi: 10.1080/14697017.2018.1459784.

[141]G. Giorgi, D. Dubin, and J. F. Perez, "Perceived organizational support for enhancing welfare at work: A regression tree model," Front. Psychol., vol. 7, no. DEC, pp. 1-9, 2016, doi 10.3389/fpsyg.2016.01770.

[142]H. Ahmad and M. Qadir, "Dimensions of Perceived Over Qualification, Perceived Organizational Support and Turnover Intentions," J. Manag. Hum. Resour., vol. 1, pp. 18-33, 2018, doi: https://econpapers.repec.org/RePEc:ksb:joumhr:v:1:y:2018:p:18-33.

[143]J. D. Smith, "Successful Strategies for Reducing Employee Turnover in the Restaurant Industry," 2018
[144] S. Sarkum, B. A. Pramuka, and A. Suroso, "A Strategy Engagement in Marketing: A Reviews of the Literature,” Int. J. Sci. Basic Appl. Res., vol. 33, no. 2, pp. 120-127, 2017, doi: 10.31227/osf.io/kw9uz.

[145]O. Saoula and H. Johari, "The Mediating Effect of Organizational Citizenship Behaviour on the Relationship between Perceived Organizational Support and Turnover Intention: A Proposed Framework,” Int. Rev. Manag. Mark., vol. 6, pp. 345-354, Jul. 2016, [Online]. Available: https://www.econjournals.com/index.php/irmm/article/view/3950/pdf.

[146]Chan Sweet LY, K. H. Yeah, L. C. Fei, N. K. Mun, and S. W. Choo, "High Performance Work System (HPWS) and turnover Intention in Malaysia Retail Industry," 2017.

[147]G. Saridakis and C. Cooper, Research Handbook on Employee Turnover. Edward Elgar Publishing, 2016.

[148]R. Islam and A. Z. H. Ismail, "Employee motivation: A Malaysian perspective," Int. J. Commer. Manag., vol. 18, no. 4, pp. 344-362, 2008, doi: 10.1108/10569210810921960.

[149]D. P. Moynihan and S. K. Pandey, "Finding workable levers over work motivation: Comparing job satisfaction, job involvement, and organizational commitment," Adm. Soc., vol. 39, no. 7, pp. 803-832, 2007, doi: 10.1177/0095399707305546.

[150]R. N. Kanungo, "Measurement of job and work involvement," J. Appl. Psychol., vol. 67, no. 3, pp. 341-349, Jun. 1982, doi: 10.1037/0021 9010.67.3.341.

[151]T. A. Joiner and S. Bakalis, "The antecedents of organizational commitment: The case of Australian casual academics," Int. J. Educ. Manag., vol. 20, no. 6, pp. 439-452, 2006, doi: $10.1108 / 09513540610683694$.

[152]H. L. Wan, "Relationship between organisational justice and organisational citizenship behaviour: Examining the mediating role of job satisfaction,” Manag. Organ. Concepts, Tools Appl., no. 2008, pp. 77-97, 2017, doi: 10.18515/dbem.m2017.n02.ch07.

[153]J. P. Leider, E. Harper, J. W. Shon, K. Sellers, and B. C. Castrucci, "Job satisfaction and expected turnover among federal, state, and local public health practitioners," Am. J. Public Health, vol. 106, no. 10, pp. 1782-1788, 2016, doi: 10.2105/AJPH.2016.303305.

[154]M. Serreqi, "Relationship of Pay and Job Satisfaction," Eur. J. Mark. Econ., vol. 8659, no. August, pp. 116-122, 2020.

[155] Ishaq Ibrahim, Kalsom Ali, and Abdul Rahim Zumrah, "An Empirical Study: The Mediating Role of Job Satisfaction on the Relationship between Belongingness and Employee Retention in Malaysian Manufacturing Industry,” Int. J. Emerg. Technol., vol. 10, no. 1, pp. 11-21, 2019.

[156]X. (Roy) Zhao, R. Ghiselli, R. Law, and J. Ma, "Motivating frontline employees: Role of job characteristics in work and life satisfaction," J. Hosp. Tour. Manag., vol. 27, pp. 27-38, Jun. 2016, doi: 10.1016/j.jhtm.2016.01.010.

[157]M. K. Ahuja, K. M. Chudoba, C. J. Kacmar, D. Harrison McKnight, and J. F. George, "It road warriors: Balancing work-family conflict, job autonomy, and work overload to mitigate turnover intentions," MIS Q Manag. Inf. Syst., vol. 31, no. 1, pp. 1-17, 2007, doi: $10.2307 / 25148778$.

[158]M. S. Ab Talib, "Motivations and benefits of halal food safety certification," J. Islam. Mark., vol. 8, no. 4, pp. 605-624, 2017, doi: 10.1108/JIMA-08-2015-0063.

[159]A. Papa, L. Dezi, G. L. Gregori, J. Mueller, and N. Miglietta, "Improving innovation performance through knowledge acquisition: the moderating role of employee retention and human resource management practices," J. Knowl. Manag., 2018, doi: 10.1108/JKM09-2017-0391.

[160]A. Presbitero, B. Roxas, and D. Chadee, "Looking beyond HRM practices in enhancing employee retention in BPOs: focus on employee-organisation value fit," Int. J. Hum. Resour. Manag., 2016 doi: 10.1080/09585192.2015.1035306. 